\title{
Socio-technical regimes and heterogeneous capabilities: the Swedish pulp and paper industry's response to energy policies
}

\author{
Mikael Ottosson and Thomas Magnusson
}

\section{Linköping University Post Print}

\section{Tweet}

N.B.: When citing this work, cite the original article.

This is an electronic version of an article published in:

Mikael Ottosson and Thomas Magnusson, Socio-technical regimes and heterogeneous capabilities: the Swedish pulp and paper industry's response to energy policies, 2013, Technology Analysis \& Strategic Management, (25), 4, 355-368.

Technology Analysis \& Strategic Management is available online at informaworldTM: http://dx.doi.org/10.1080/09537325.2013.774349

Copyright: Taylor \& Francis (Routledge) http://www.routledge.com/

Postprint available at: Linköping University Electronic Press http://urn.kb.se/resolve?urn=urn:nbn:se:liu:diva-90552 


\title{
Socio-technical regimes and heterogeneous
}

\section{capabilities: The Swedish pulp and paper industry's}

\section{response to energy policies}

\author{
Mikael Ottosson (corresponding author) ${ }^{a, *}$, Thomas Magnusson ${ }^{b}$ \\ ${ }^{a}$ The Department of Management and Engineering, Division of Business Administration, \\ ${ }^{\mathrm{b}}$ The Department of Management and Engineering, Division of Project, Innovation and \\ Entrepreneurship, \\ Linköping University, \\ SE-581 83 Linköping, Sweden \\ e-mail: mikael.ottosson@liu.se \\ phone: +4613282260
}

\begin{abstract}
Based on a study of policy-induced changes in the Swedish pulp and paper industry, this paper follows a process of socio-technical regime destabilisation. Results from the study show that in industries where established firms have significant power, processes of endogenous renewal are more likely to destabilise established regimes than processes based on niche solutions. Further, the study shows how policy measures aimed to destabilise the current regime may result in different responses, due to the different capabilities of individual firms. The analysis suggests that heterogeneous capabilities within established industries provide possibilities for policy makers to initiate change.
\end{abstract}

Keywords: pulp and paper industry, energy, socio-technical regime, transition, capabilities 


\section{Introduction}

The pulp and paper industry is a well-established, mature industry, with a legacy of several hundred years. This substantially energy and capital-intensive industry plays a significant role in the Swedish economy; of total industry employment, exports, sales and added value, the pulp and paper industry (including the saw mills) account for approximately 10-12 percent (SFIF, 2010). During the 20th century, supported by national energy policies that promoted energy security and independence through domestic production, the Swedish pulp and paper industry became very dependent upon low electricity prices. However, between the years 2000 and 2011, the industry began to prioritize energy efficiency (Thollander and Ottosson, 2008, Stenqvist et al 2011. Ericsson et al 2011). Significant investments in process technology, as well as a focus on process innovation and optimization, resulted in a reduced annual electricity consumption of 1 TWh by 2011, a figure which represented $4.35 \%$ of the industry's total electricity use that year (23 TWh). Moreover, through investments in new generators and steam turbines, pulp and paper mills could use the process heat, which had previously been wasted, for renewable electricity production. These investments turned the Swedish pulp and paper industry into one of the major renewable energy producers in the country. In 2011, the industry produced $6 \mathrm{TWh}$ of renewable electricity from biomass, a figure that represents an increase by 2 TWh in renewable electricity production during the 2000-2011-period.

This paper analyses the role of national energy policies in facilitating this significant change. Our empirical case describes how the Swedish pulp and paper industry has been involved in the design of the two most important national public policy instruments targeting the industry during the 2000-2011-period, the Electricity Certificate System (ECS) and the Programme for Improving Energy Efficiency in Energy Intensive Industries (PFE), and it also shows how these instruments have affected the industry. The aim of the 
paper is to understand how the implementation of goal-directed policy instruments may serve to destabilise and facilitate major change in a well-entrenched and seemingly stable industry.

The paper is structured in the following way. First, it presents an analytical framework building upon ecological modernization, evolutionary economics and the multi-level perspective (MLP) of socio-technical transformation. The next section presents the research methods underpinning the paper. This is followed by a section which presents the Swedish pulp and paper industry. The next two sections analyse the case as a co-evolving change process involving a number of different actors. The final section outlines the general conclusions and implications from the analysis.

\section{Analytical framework}

An increasing number of scholars have argued that industrial firms have the ability to restructure and reorganize their businesses, moving towards 'ecological modernization' (Hajer, 1995; Mol, 2003). Spaargaren and Mol (1992, p. 334) argue that 'Ecological modernization stands for a major transformation, an ecological switch of the industrialization process into a direction that takes into account maintaining the sustenance base'. Ecological modernisation can be contrasted with what the sociologist, Ulrich Beck, has referred to as 'industrial modernity' (Beck, 1997, p.113), i.e. a notion that industry's overall mission is to create economic profit which results in employment, export revenues, and social welfare. The concept of ecological modernization mergers the business profit aims and the social responsibilities which are inherent in industrial modernity, with ecological sustainability motives. 
Among those who are most positive towards ecological modernization are Porter and Van der Linde (1995), who argue that environmental standards, laws, and taxes trigger innovations that can completely offset the costs of compliance. Porter and Van der Linde provide several empirical examples of companies that have increased their profitability by instituting pollution control or material reduction.

Still, sustainable development is an open-ended process which depends on different actors with different perspectives and varying interpretations of what is sustainable (Smith \& Stirling, 2007; Kemp \& Rotmans, 2009). Further, different countries have different prerequisites in terms of industrial production, innovation systems, and energy resources, and the complexity and uncertainty associated with transformations towards sustainability mean that it is difficult to foresee the consequences of individual initiatives. Hence, in order to advance societal sustainability objectives, it is necessary to have a steering and coordination which is open, creative and self-critical (Voß et al, 2006; Hendricks \& Grin, 2007). Research associated with evolutionary economics and innovation studies argues that firms in mature industries are often unwilling to make major changes (Dosi, 1984, Nelson and Winter, 1982). In such industries, the rate of product innovation is low, and focus is instead on process innovation intended to increase productivity and profitability. Dosi (1984, ch. 2) argues that firms tend to be locked into current technologies, products and markets, due to their shared cognitive beliefs or paradigms.

Researchers adopting the multi-level perspective on socio-technical transformation (MLP) have argued for the need to 1) support the emergence of alternative 'more sustainable' socio-technical configurations (niches); 2) to destabilise/unsettle/unlock established sociotechnical configurations (regimes); 3) to facilitate processes for translating more sustainable socio-technical configurations from limited niches to mainstream practice 
(Geels, 2002; Smith et al, 2010; van den Bergh et al, 2011). This has to be done under the influence of external 'landscape' factors. Much of the research related to the MLP has focused the specific role of niches, i.e. protected spaces that allow for testing, experimentation, demonstration, adaptation, and further improvement of new technologies which are not yet competitive on regular markets (Kemp et al., 1998; Smith, 2003; Smith, 2007; Hegger et al, 2007). However, Smith et al. (2005) and Schot and Geels (2007) have cautioned against too much focus upon niche-based agency in transitions towards sustainability, arguing that niche-external processes may also be required to realise industrial transformations. The critique finds support in a study of government-funded support programmes for low-energy housing technologies in the UK that shows how niche policies have provided weak incentives for change (Lowell, 2007). To have an effect, policies need to confront the interests of powerful stakeholders who operate on a regimelevel in the existing socio-technical system.

Geels (2004) argues that socio-technical regimes are the 'rule set' that guide the evolution of the system. This 'rule set' is closely associated with the concept of institutions that affect knowledge production, investments, material objects, values and norms, industrial structures, markets, policies and regulations (Smith et al., 2005). The stability of the regime is preserved by the socio-technical practices executed by a number of different stakeholders, such as governmental agencies, single firms and business associations. However, change occurs, and is often driven by wider changes in the surrounding landscape, such as environmental change, new social movements, broad economic restructuring, and emerging scientific paradigms (Smith et. al. 2010). Landscape changes are sources of pressure upon the regime level which prompt responses and stress actors within the regime to react. Dynamics within regimes may also be triggered by initiatives 
which target particular regimes, such as R\&D investments or sector-specific government regulations.

\section{Research methods}

This paper analyses a co-evolving change process. The process comprises a number of different actors including the Swedish state, the Swedish Energy Agency (SEA), the Swedish Forest Industry Federation (SFIF) and individual pulp and paper industry firms. The analysis is based on data gained from interviews, visits to industrial sites, empirical data from the SEA, and industry and firm documents to triangulate the case and strengthen its reliability (Neuman, 2011). We conducted semi-structured interviews between 2007and 2011 with representatives from the Swedish Ministry of Enterprise, Energy and Communications (the body for the Energy Policy), the SEA, the SFIF, and individual pulp and paper producers. The interviews lasted from 45 minutes up to several hours, in cases when they were combined with a walk around site.

Two categories of personnel at the pulp and paper producers were interviewed; people responsible for energy issues (energy managers) and the mill managers. The energy managers were interviewed because they are the people most likely to be able to answer questions regarding the mill's energy investments, process innovations and long-term energy strategy. The mill managers were interviewed to obtain answers concerning issues such as the future strategies of the mill and of the corporation. The industrial site visits also provided us with considerable knowledge of issues such as industrial energy use, energy sources, energy markets, and the complexity of large-scale industrial sites. The interviews and site visits at Vallvik pulp mill and Värö pulp mill capture two illustrative examples of the effects upon individual firms of the ongoing change process. 
In order to capture the opinion of the business association, an interview was also conducted with the energy director of the SFIF. Two interviews were also conducted with people responsible for the development of, and continuous work with, the ECS and the PFE. Through these interviews we could capture the design, implementation and results of the public policy intervention.

The interview data was complemented with information obtained from the SEA about energy related measures, practices and investments reported by 41 pulp and paper industry firms participating in the PFE. This rich data allowed us to analyze the specific investments and process innovations that the ECS and PFE triggered, as well as the direct effects in terms of electricity savings and investments in renewable electricity production. However, it is important to state that this is a complex process, in which different factors such as electricity price increases, the ECS and the PFE together drive energy efficiency and increased renewable electricity production. By triangulating different sources of data, we were able to trace this process.

\section{The Swedish pulp and paper industry}

Sweden is a major pulp and paper producing nation. The industry's four largest firms, SCA, Södra, Stora Enso and Holmen, jointly account for approximately 64\% of the pulp and $60 \%$ of the paper production in the country (SFA, 2011). These four firms have historically been competitors, but today, have to a large extent diversified into different market segments.

The Swedish pulp and paper industry annually uses around $50 \mathrm{TWh}$ of biomass, $23 \mathrm{TWh}$ of electricity and around 2.5 TWh of fossil fuels (Palm, 2011).Therefore energy plays an important role in its operations. In 2007, the purchase of energy and raw material (basically 
pulpwood, and electricity) accounted for $56 \%$ of total operating expenses in the industry (Ericsson et. al., 2011). In 2002, approximately $70 \%$ of the pulp produced in Sweden was chemical pulp while approximately 30\% was mechanical pulp (Möllersten, 2002). These two different types of pulp derive from different end-product functionalities. Energy use differs radically between the two processes. While chemical pulping mainly uses biomass as the primary energy source, mechanical pulping mainly uses electricity. When grinding the wood in mechanical pulping, up to $95 \%$ of the wood is converted into end products. In the chemical process, approximately $50 \%$ of the wood (mainly the lignin in the wood that is dissolved in the black liquor) is used for energy purposes, and the remaining $50 \%$ is converted into end products (Theliander et al, 2002). In practice, this major difference means that the different types of mills have diametrically different profitability criteria. For example, many chemical pulp mills have the potential to become electricity producers, since burning the black liquor that contains lignin produces surplus steam, which can be transformed into electricity in steam turbines. The mechanical mills, on the other hand, are huge net users of electricity. Taken together, ceteris paribus, this means that a higher electricity price increases profitability in chemical pulp mills while the opposite holds for the mechanical mills.

A pulp and/or paper mill is a technically complex and capital intensive industry facility (Ojala et al., 2006). A paper machine costs several hundred million euro to install, while a new recovery boiler may cost up to 200 mEUR. To produce pulp and paper competitively requires significant economies of scale and large amounts of invested capital. Naturally, these circumstances result in a high degree of technological path dependence in the industry. Previous research analyzing the industry has demonstrated that pulp and paper producers are reluctant to embrace major technological change (Laestadius, 2000, Bergek, 2002). 


\section{Destabilising an industrial modern socio-technical regime}

This section describes the dialogue between the Swedish state, the Energy Agency and the pulp and paper industry in the construction and implementation of the ECS and PFE, illustrating how the Swedish state strived to break with the industrial modernity that had marked the pulp and paper industry for decades.

\subsection{The 'colourization' of electricity with the introduction of the ECS}

In 1997, the Swedish Social Democratic Government argued that Swedish industry should spearhead the move towards ecological sustainability, something that would provide great competitive advantages on the promising green markets, and create new 'green' jobs (Lundqvist, 2000). In the bill 1996/97:84 En uthållig energiförsörjning the Social Democratic government reached an important agreement with the Centre party as well as the Left party to close the Barsebäck nuclear power plant. In order to replace the electricity produced by the nuclear power plant, a number of different support systems for renewable energy were launched. However, as these support systems ended in 2002, the government wanted to investigate other, longer-term policy instruments to increase renewable electricity production (Blümer, 2011). The choice fell upon the ECS, which was introduced in 2003.

The ECS was an important tool for the Swedish government in its attempts to increase the proportion of renewable energy as originally stipulated in Directive 2001/77/EC. The ECS is a market-based support system that allows for competition between different renewable electricity sources which compete against each other. This is said to make the cheapest method of producing renewable electricity the one that will be favoured by the energy 
producers. In practice, this is accomplished by the fact that the market value of the electricity certificates (i.e. their support to the producers) are determined by their supply and demand, which is the same, regardless of the type of renewable energy source used in the production of electricity (SEA, 2009b).

The carrot for producers of renewable electricity is that they receive one electricity certificate for each megawatt-hour (MWh) of renewable electricity that they produce. The ECS therefore increases the value of renewable electricity, as electricity producers can sell the certificate as well as the electricity on the market. The system is guaranteed by the socalled 'quota obligation', which means that all electricity suppliers, and also many electricity users, are required to purchase certificates corresponding to a proportion (quota) of their electricity sales or electricity use. In order to generate an increasing demand for the certificates, the Swedish State changes the quotas from year to year, but the levels have been decided on until 2035. By these means, the objective of the ECS is to increase the production of renewable electricity by 25 TWh by the year 2020 (SEA, 2009b).

During the preparation of the ECS an expert group was created. Amongst others, it included a representative from the SFIF. The SFIF had a double interest with regards to the design of the ECS. First, it was very important for the SFIF that the pulp and paper industry should be exempted from the quota obligation, which would mean that the industry would be required to purchase certificates corresponding to the proportion (quota) of their electricity use. Naturally, this would have resulted in extensive costs to the industry, given that it uses 23TWh electricity per year. Second, the SFIF wanted to include the pulp and paper industry's chemical pulp mills in the system, since these have the ability to produce 'green' electricity from biomass through the use of back-pressure (SOU 2001:77). 
In the preparatory work before the final design of the ECS, it was not self-evident that the pulp and paper industry should be exempted from the quota requirement. In the electricity certificate investigation (SOU 2001:77), one of the experts, Christer Söderberg, argued that: 'A general exemption for the so called electricity intensive industry may lead to too many 'free-riders'. This type of subvention neither promotes production efficiency, nor technical development within electricity intensive industry.' (SOU 2001:77, p. 241).

The government, however, decided that the pulp and paper industry, as well as other electricity dependent industries which use more than $10 \mathrm{MW}$ of electricity, was to be exempted from the quota obligation. The argument from the government was that the industry already faced costs in terms of taxes and charges, and that the quota requirement would add yet more costs which would decrease the electricity intensive industries' international competitiveness (SOU 2001:77).

The pulp and paper industry's mills that produce 'green' electricity were included in the ECS from 2003 and onwards. This was because a number of existing power plants, such as district heating CHP plants, had the capacity to increase their renewable electricity production. According to Blümer (2011), there was a fear that there would be too little liquidity in the system if only new production plants were to be included. It was also believed that there was a need to support the conversion from fossil fuel to biofuel in CHP plants, since without support the biofuels could scarcely compete. Moreover, not including the existing production could be seen as punishing 'front-runners' and it would also involve the risk of existing biomass CHP plants switching to coal, and then after minor investments back again to biomass which would make them eligible for certificates ${ }^{1}$. The specific reason for including the pulp and paper industry was also discussed in a

\footnotetext{
${ }^{1}$ This insightful note was raised by an anonymous reviewer.
} 
government-led investigation, which argued that Swedish pulp and paper mills had produced 4.4 TWh of electricity through the use of back-pressure in the year 2000, and that with current technology; this production could increase to 5.25 TWh (SOU 2001:77, p. 79$80)$.

It is thus reasonable to argue that the inclusion of the pulp and paper industry in the ECS was a win-win situation for both the pulp and paper industry and the Swedish state, since it would increase 'green' electricity production and also create a new attractive source of income for the pulp and paper industry. In that sense, the ECS could combine both economic (industrial policy) considerations as well as increase the amount of 'green' electricity produced.

\subsection{Increased focus on energy efficiency - the introduction of the PFE in 2005}

As early as in the late 1990s, the Swedish state had started to investigate a long-term agreement with energy intensive firms on measures to improve energy efficiency. In the preparation phase, a reference group with representatives from energy intensive industries had been created. The reference group, together with the SEA, created the Swedish Standard for Energy Management Systems (EMS) which later became the 'engine' in the PFE (Björkman, 2011). Pulp and paper industry representatives were particularly active in this work.

Initially, it was unclear what type of incentive firms would have for joining PFE. However, in 2004, through the introduction of the European Union's Energy Tax Directive, Sweden was forced to introduce a tax on industrial process-related electricity use. The tax amounted to SEK 0.005 per $\mathrm{kWh}$ electricity. In Sweden, there had been a political conviction that such a tax would be harmful for electricity intensive industries' 
competiveness, and therefore the ambition was to turn the PFE into a carrot for a reduced tax on electricity-use. On 1 January 2005 , Sweden introduced the PFE with the intention to increase energy efficiency in energy intensive industries such as the pulp and paper industry, the chemical industry, the steel industry and the mining industry. PFE was designed to give energy-intensive firms a guaranteed tax exemption if they joined the programme and followed its mandatory requirements (SEA, 2011a).

The programme period was five years. During the first two years, the participating firms had to implement standardized certified EMS. The standard stipulated three different types of energy related improvements that the firms should continuously work with. These were 1) energy efficiency (including electricity, heat and fuel) 2) an increased use of renewable energy carriers, and 3) an increased renewable energy production and/or sales. In practice, this meant that when a firm joined the PFE, they were forced to work with potential improvements within all these areas. An independent auditor later investigated whether or not the firm had followed the EMS.

An extensive energy review was carried out, resulting in a list of energy efficiency measures (investments and managements/organizational issues), which the firm had to implement during the next three years (SEA, 2011a). While the PFE focused on electricity efficiency, the fact that the whole programme centred on the implementation of EMS gave the programme a wider role, increasing the participating firms' knowledge about their entire energy use and facilitating a more planned and structured energy strategy (Björkman, 2011, Petersson, 2011). The SEA stated: 'With more conscious planning, improved operating and maintenance procedures and purchasing procedures, companies can reduce their energy consumption and, therefore, their energy costs and their negative environmental impact' (SEA, 2011a). After being in the programme for five years, the firm 
had to submit a final report to the SEA, specifying the actual results of the energy efficiency measures.

By the end of the period, a significant part of the programme had become centred on the organization of workshops with industry representatives on both a regional and a national level. The programme board was particularly important in this context. As the board consisted of representatives from a range of different industries, their meetings developed into an important forum for sharing experiences related to the PFE.

\section{The effects of the ECS and the PFE on the industry}

Both the ECS and the PFE were implemented during a period characterised by increasing electricity prices for the industry. According to a rough estimation given by Ericsson et al. (2011) electricity prices for the Swedish industry increased from around 20-25 EUR/MWh in the late 1990s to around 45 EUR/MWh by the end of the 2000s. The focus on energy efficiency encouraged by the PFE thus further underlined the importance of energy efficiency, while the ECS encouraged renewable electricity production.

\subsection{Direct effects on the industry}

With the 2003 introduction of the ECS, the profitability of renewable electricity production in the Swedish pulp and paper industry began to increase. In particular, the ECS made it profitable for chemical pulp mills to produce renewable electricity from biomass by using back-pressure. Pulp and paper producers that became renewable electricity producers earned a double income: the wholesale price, plus the revenue from sales of electricity certificates (SEA, 2009a). The ECS enabled a number of investments in terms of new and/or larger turbines, as well as in generators to increase 'green' electricity production (Palm, 2011). These investments ranged from a few million up to 20 million EUR. Several 
firms also made significant investments (above a hundred million EUR) in new high pressure recovery boilers. These investments were certainly production related, but they also increased the companies' ability to produce more electricity, and this influenced the investment decisions. The annual production of renewable electricity using back-pressure at the pulp and paper mills increased by 2 TWh to approximately 6 TWh 2003-2011 (SFIF 2010). All in all, the ECS is the main explanation for this rapidly increased production of 'green' electricity. ECS also encouraged large-scale wind-power investments on the pulp and paper firms' land. In 2011, SCA alone presented concrete investment plans to facilitate annual production of 4.6 TWh renewable electricity from wind turbines on their forest land (Shape, 2011, p. 14).

The implementation of EMS within PFE also meant that pulp and paper industry firms had to consider energy consumption in investments that were made for reasons other than energy-related issues (Petersson, 2011). Table 1 shows a selection of the investments reported by Swedish pulp and paper producers to the SEA as a result of their participation in PFE. These investments were much smaller than the investments made in generators and turbines, but as is evident from the table, the net reduction in terms of electricity use is still significant.

Table 1. Selected examples of investments reported to the SEA (2011b).

\section{INSERT TABLE 1 HERE}

As a result of the PFE, the 41 participating pulp and paper producers reported total electricity savings of $1 \mathrm{TWh}$ per year, which is equivalent to approximately $4.35 \%$ of the 
industry's total use (23 TWh), during the first five years of the programme (2004-2009) (Palm, 2011). Given the technically complex and capital intensive nature of this industry, electricity savings of $1 \mathrm{TWh}$ per year is a significant improvement. The majority, about $75 \%$ of the direct investments, was related to support processes such as fans, pumps, and engines. However, when considering the electricity efficiency gained, the investments that were related to the production process ( $25 \%$ of the total investments) resulted in $50 \%$ of the savings (SEA, 2009c). Hence, investments related to core processes were more effective than investments related to auxiliary systems.

\subsection{Indirect effects upon the industry}

While ECS affected the industry in terms of increasing the profitability in investment calculations, through the implementation of the EMS, PFE increased the focus on energy efficiency, the use of renewable energy, and the focus on energy production and/or sales. All these issues are inter-connected in a pulp mill and involve finding optimal steam pressure, steam balance and energy balance in the production process (Björkman, 2011). Such process optimization is a continuous task for the energy managers at the mills. Since every pulp mill is unique and is rebuilt over the decades time and time again, with different engines, fans, pumps, generators, boilers and turbines, this work also includes the identification and remediation of inefficiency and leakages. The EMS implementation provided a useful tool for the continuous work with process innovation at the mills (Palm, 2011; Björkman, 2011; Petersson, 2011).

Both Björkman and Petersson (2011) stress the importance of PFE in terms of increasing energy managers' knowledge about energy flows at the mills. Björkman (2011) stresses that a number of firms started to work with a system perspective in their energy 
management. Since purchases of equipment and the projection of new investments had to include energy estimates, the pulp and paper producers also had to improve their knowledge of energy-related issues. Training thus increased within the firms. Table 2 provides a number of illustrative examples of measures which reduced the use of energy in the Swedish pulp and paper industry during the programme period. The table highlights the significance of process optimization and also shows that the measures were related to a range of different technologies and different parts of the process.

Table 2. Selected examples of measures reported to the SEA (2011b).

\section{INSERT TABLE 2 HERE}

Björkman and Petersson (2011) also stress that that the PFE played a part in making energy a more strategic issue in the pulp and paper industry during the period 2004-2009. Palm (2011) also believes that the strategic focus upon energy within the industry has increased due to ECS and PFE. In practice, this means that the mill managers, the CEOs and the boards of directors have increased their acceptance of energy related investments. The long term effects of PFE, however, have probably not yet been seen, given that the EMS is based on a structured long-term learning process at the mills (Björkman, 2011). Therefore, the PFE has the potential to contribute to increased energy efficiency and increased renewable energy production to an even greater extent in the future.

\subsection{The effects on single firms - two illustrative examples}

To illustrate the effects of the change process on individual firms, this section compares two incumbents within the Swedish pulp and paper industry, Södra and Rottneros. These firms have many similarities. They were both part of the PFE, which means that we have 
data about their energy efficiency practices as well as other energy related investments as a basis for comparisons between the firms. Both firms are also large producers of market pulp, a product with a low degree of added value. However, even though Södra and Rottneros are similar in many respects, they are quite different in terms of the process technologies used in their production facilities.

In 2004, Södra had three chemical pulp mills in Sweden, while Rottneros had three mechanical pulp mills and one chemical pulp mill. The differences in production processes in these two firms exemplify how the change affected the pulp and paper industry. The Södra forest industry group is an example of a firm that came out as a winner in this development. Since 2003-2004, when ECS and PFE were introduced, Södra's strategy has focused on investments that increase their potential to sell energy, i.e. green electricity and excess heat. In 2006 and 2007, for example, 50-60\% of Södra's investments were energyrelated, and in 2008, the figure had reached 80\% (Andersson, 2007; Edvinsson, 2008). In 2011, Södra had become Sweden's biggest producer of biomass electricity, producing 1.8 TWh per year (Södra, 2009). During the period 2006-2009, Södra delivered steady profits and was still able to make investments. Besides investing in their mills to increase production of electricity from biomass, their investments involved windpower, district heating co-operations with local communities, a new sawmill, and a new dissolving pulp production line. In total, these were investments of hundreds of millions of euro. A look at the results for the 2004-2009 PFE period shows 75 individual investments and/or process innovations that helped them both to increase their production of 'green' electricity and to reduce electricity use. On a voluntary basis, the firm reported 32 additional practices that either increased their energy efficiency (including the use of heat and fuel) or the production of district heating which was delivered to nearby communities. 
The Rottneros corperation, on the other hand, made losses every year between 2006 and 2009. They were forced to close their mechanical pulp mill, Utansjö, and divest their mechanical pulp mill, Rockhammar, due to increasingly higher electricity prices. The Utansjö mill was among those Swedish mills that were most vulnerable to higher electricity prices, due to their use of mechanical pulping and their lack of a long-term electricity contract. The mill consisted of two pulp production lines, one chemi-thermomechanical pulp (CTMP) line, which started production as recently as 2005, and one older, ground wood-line. The electricity price was circa EUR 23 per MWh when the investment of EUR 30 million was made, but reached EUR 70 per MWh in 2006 (SKGS, 2006). The results for the 2004-2009 PFE period reveal 17 investments and/or process innovations, and another two voluntary measures.

Even though factors other than the ECS and PFE may be important explanations of Rottneros' difficulties and Södra's success, these public policy instruments served to reinforce the current trends in the industry. The industry today is increasingly divided into two distinctive parts with different profitability criteria: mechanical pulping and chemical pulping. Chemical pulp mills have reached higher revenues while simultaneously increasing their demand and capacity to pay for pulp wood. By contrast, the mechanical pulp mills have not benefitted correspondingly from the ECS (Hirsmark, 2005). Consequently, firms within the industry have shifted investments from mechanical pulp mills to chemical pulp mills. For example, since 2007, Rottneros has been investing in a new turbine at its Vallvik chemical pulp mill focusing on increased production of green electricity. On the other hand, they cancelled investments in their mechanical pulp millssince the financial resources were limited (Thomasfolk, 2007). 
The Södra and Rottneros cases thus demonstrate that the changing energy policy in Sweden - moving from a regime built upon low electricity prices to a regime which focus upon energy efficiency and renewable electricity production -changed the profitability criteria for the whole pulp and paper industry. Still, on a firm level, the effects of the pressure from policy instruments differed greatly, depending on heterogeneous production processes, facilities and technologies. While Södra was able to increase its share of the growing 'green' markets for renewable electricity, bio-fuels and tall oil, Rottneros was locked into an electricity-intensive production process disfavoured by the drift from industrial modernity towards ecological modernisation.

\section{Discussion and conclusions}

After 1945, Swedish producers increasingly invested in large-scale integrated facilities for the production of pulp and paper and bulk products. Sweden's comparative advantages have often been cited by industry representatives when they justify the development path taken by this industry. The arguments put forward have been that cheap hydroelectric power gave the Swedish pulp and paper producers an advantage over their competitors after the Second World War (Melander, 1997, p. 306). This advantage was reinforced through a rapid expansion of nuclear power in Sweden during the 1970s (Anshelm, 2000). Consequently, industrial modernity has been the basis of Swedish national energy policies for a number of decades, resulting in low and stable electricity prices for the pulp and paper producers. Industry representatives have also stressed this as a historical explanation for the differences between the Swedish and Finnish pulp and paper industries. Compared to Finland, Sweden has a higher degree of mechanical pulp production. The Swedish industry also uses a lower degree of recycled fibre than its competitors. Historically low electricity prices, as well as a historical fear of wood shortage, have also been maintained as the prime 
explanations for the Swedish forest industry's dependency on electricity (Skog \& Industri 2006, pp.11-16).

However, our case study shows that it has been possible to accomplish major change in this well-entrenched and seemingly stable industry. The study demonstrates a transformation from a regime built on the assumption that electricity prices would be low and stable, to a regime striving for energy efficiency. In this transformation process, changes have been realised through an interplay between private and public actors; an interplay that has fostered incremental reforms to reduce energy consumption. Notwithstanding the incremental nature of these reforms, the results have been significant in terms of energy savings. Moreover, the transformation has fostered increased electricity production from renewable sources, comprising well-known technologies such as back-pressure steam turbines as well as alternative technologies such as wind-turbines, with which the established industry actors have been less familiar.

Even though the ambition of the policy actors has been to promote sustainable development in a dialogue with industry - taking both environmental and economic issues into consideration - unintended consequences have still occurred. Our case study thus illustrates the difficulty of foreseeing the consequences of individual policy measures. The study also shows how policy makers face an inherent dilemma in this respect. In capital intensive sectors such as the pulp and paper industry, heavy investment decisions have to be justified on a long term basis. To facilitate investment decisions, policy makers therefore need to provide a stable framework and direction for the future, something that, in turn, restricts the possibilities for continuous adaptation. Voß et al (2006) term this dilemma between steering and flexibility 'the efficacy paradox of complexity', arguing that 
there is no simple solution. Still, all policies aiming for sustainable development will have to face this.

In addition, the case illustrates the point raised by Smith et al (2005) and Lowell (2007), namely that solely relying on niches as the force that will enable industrial transformation is insufficient. Our case study analysis conveys a few important lessons about this. By its very nature, the pulp and paper industry is extremely energy and material intensive. Just like other energy and material intensive process industries, e.g. steel production and petrochemicals, the pulp and paper industry is also very capital intensive. Barriers for new entrants are therefore high, and established actors have significant political power. In such industries, a high degree of steering and coordination is necessary to enact changes, and endogenous processes of renewal will be preferred. Addressing established interests and stakeholders in the design and implementation of policies for industrial transformation will therefore be critical.

Moreover, our study shows how diverging responses to landscape changes and new policy instruments must be understood in relation to individual firms. The notion of heterogeneity among firms operating within the same industry is well-anchored in strategic management literature (Barney \& Hesterley, 2005; Teece, 2007). According to this literature, unique capabilities in terms of knowledge, technology, production facilities, distribution systems and brands are the prime source of competitive advantage, and this heterogeneity tends to persist even in seemingly stable industries. With a few exceptions (van den Bergh 2008, Stirling, 2011) this perspective has been largely neglected in literature adopting the multilevel perspective on socio-technical transformations. Defining regimes as the sets of rules that guide system evolution (Geels, 2004), this policy-oriented literature has described established socio-technical systems as relatively homogenous entities. However, our 
findings show how heterogonous capabilities in terms of production processes, facilities and technologies within an established industry imply that the possibility to benefit from changes differs between different actors. Hence, investment decisions are not only guided by common sets of rules within the industry, but also by the capabilities of individual firms. Rather than arguing for the ability of all firms to easily go green (Porter and Van der Linde, 1995), policy makers can make use of this insight in the design and implementation of policy instruments. Heterogeneous capabilities will result in greater possibilities to influence presumably conservative structures and induce processes of endogenous industrial transformation.

\section{References}

Andersson, C., 2007. Interview with Christian Andersson, Energy manager at Södra Värö pulp mill, 2007-04-16.

Anshelm, J., 2000. Mellan frälsning och domedag. Om kärnkraftens politiska idéhistoria i Sverige 1945-1999. Stockholm: Brutus Östlings Bokförlag Symposion.

Barney, J. B., Hesterley, W. S., 2005. Strategic management and competitive advantage. New Jersey: Pearson - Prentice Hall.

Beck, U., 1997. The reinvention of politics: Rethinking modernity in the global social order. Cambridge: Polity Press.

Bergek, A., 2002. 'Responses to a technological opportunity: The case of black liquor gasification in Sweden'. In Shaping and exploiting Technological opportunities: The case of renewable energy technology in Sweden. Göteborg: Chalmers university of technology. 
Björkman, T., 2011. Executive officer and project manager at the Swedish Energy Agency. Recorded telephone interview 2011-06-23.

Blümer, M., 2011. Deputy Director at the Division for Energy at the Ministry of Enterprise, Energy and Communications. Recorded telephone interview 2011-06-21.

Dosi, G., 1984. Technical Change and Industrial Transformation. Basingstoke: Macmillan.

Edvinsson, H., 2008. Interview with Håkan Edvinsson, Energy manager at Södra Mönsterås pulp mill. 2008-02-29.

Ericsson, K., Nilsson, L. J., Nilsson, M., 2011. New energy strategies in the Swedish pulp and paper industry-The role of national and EU climate and energy policies. Energy Policy 39, 1439-1449.

Geels, F.W., 2002. Technological transitions as evolutionary reconfiguration processes: A multi-level perspective and a case-study, Research Policy 31, 1257-1274.

Geels, F.W., 2004. From sectoral systems of innovation to socio-technical systems: Insights about dynamics and change from sociology and institutional theory, Research Policy 33, 897-920.

Hajer, M. A., 1995. The Politics of Environmental Discourse, Oxford, Oxford University Press. 
Hirsmark, J.,2005.Elcertifikatsystemetseffekter på biokraft inom massaindustrin.

SVEBIO (Svenska Bioenergiföreningen).

Dries. L. T. Hegger, Jenneke Van Vliet \& Bas J. M. Van Vliet (2007): Niche

Management and its Contribution to Regime Change: The Case of Innovation in Sanitation, Technology Analysis \& Strategic Management, 19:6, 729-746

Hendriks, C.M., Grin, J., 2007. Enacting Reflexive Governance: The politics of Dutch transitions to sustainability. Journal of Environmental Policy and Planning 9, 333-350.

Kemp, R., Schot, J., Hoogma, R., 1998. Regime shifts to sustainability through processes of niche formation: the approach of strategic niche management. Technology Analysis \& Strategic Management 10, 175-195.

Kemp, R., Rotmans, J., 2009. Transitioning Policy: Co-production of a new strategic framework for energy innovation policy in the Netherlands. Policy Sciences 42, 303-322.

Laestadius, S., 2000. Biotechnology and the Potential for a Radical Shift of Technology in Forest Industry. Technology Analysis \& Strategic Management 12, 193-212.

Lovell, L., 2007. The governance of innovation in socio-technicla systems: the difficulties of strategic niche management in practice. Science and Public Policy 34(1), 35-44

Lundqvist, L. J., 2000. Capacity-building or social construction? Explaining Sweden's shift towards ecological modernisation. Geoforum 31, 21-32. 
Melander, A. (1997) Industrial wisdom and strategic change: The Swedish pulp and paper industry, 1945-1990. Jönköping: International Business School.

Merriam, S. B., 1998. Qualitative research and case study applications in education. San Francisco: Jossey-Bass Publishers.

Mol, A. P. J., 2003. The environmental transformation of the modern order. In: Misa, T.J., Brey, P., Feenberg, A., (eds.), Modernity and Technology. Cambridge: MIT press.

Möllersten, K., 2002. Opportunities for CO2 Reductions and CO2-Lean Energy Systems in Pulp and Paper Mills. Stockholm: Doctoral Thesis Department of Chemical Engineering and Technology, Energy Processes, Royal Institute of Technology.

Nelson, R. R., Winter S. G., 1982. An Evolutionary Theory of Economic Change. Cambridge: The Belknap Press.

Neumann W. L., 2011, Social Research Methods. Pearson Education, Boston.

Ojala, J., Lamberg, J-A., Ahola, A., Melander, A., 2006. The ephemera of success: Strategy, structure and performance in the forestry industries. In Lamberg, J.-A., Näsi, J., Ojala, J., Sajasalo, P., (eds.) The evolution of competitive strategies in global forestry industries. Comparative perspectives. Dordrecht: Springer.

Palm, L., 2011. Energy director at the Swedish forest industry federation. Recorded telephone interview 2011-06-30. 
Petersson, K., 2011. Executive officer and project manager at the Swedish Energy Agency. Recorded telephone interview 2011-06-23.

Porter, M. E, van der Linde, C., 1995. Toward a New Conception of the EnvironmentCompetitiveness Relationship. Journal of Economic Perspectives 9, 97-118.

SEA (Swedish Energy Agency), 2009a. Energy in Sweden 2008. Eskilstuna: Swedish Energy Agency Publication Department.

SEA (Swedish Energy Agency), 2009b. The electricity certificate system. Eskilstuna: Swedish Energy Agency.

SEA (Swedish Energy Agency), 2009c. Resultat från PFEs första programperiod. Energimyndigheten: Eskilstuna.

SEA (Swedish Energy Agency), 2011a. About PFE. http://energimyndigheten.se/sv/Foretag/Energieffektivisering-i-foretag/PFE/Om-PFE/. 2011-11-19.

SEA (Swedish Energy Agency), 2011b. Resultat från programmet. http://energimyndigheten.se/sv/Foretag/Energieffektivisering-i-foretag/PFE/OmPFE/Resultat-fran-programmet/. 2011-11-19.

SFA(Swedish Forestry Agency), 2011. Statistical database all tables and figures: / http://www.skogsstyrelsen.se/Myndigheten/Statistik/. 2011-11-19. 
SFIF (Swedish Forest Industry Federation), 2010. Facts and figures. http://www.forestindustries.se/web/Facts_and_figures.aspx. 2011-01-30.

Shape, 2011. Vind från skogar, 14. Stockholm: SCA Corporate communications.

Schot J., Geels F.W. (2008): Strategic niche management and sustainable innovation journeys: theory, findings, research agenda, and policy, Technology Analysis \& Strategic Management, 20:5, 537-554.

SKGS (Skogen, Kemin, Gruvorna och Stålet), 2006. Elpriset skördar sitt första offer. Press release 2006-08-30.

Skog \& Industri, 2006. Högspänning på elpriserna. 4, 11-16. Stockholm: Skogsindustrierna.

Smith, A. 2003. Transforming technological regimes for sustainable development: a role for alternative technology niches? Science and Public Policy 30(2), 127-135

Smith, 2007 Translating Sustainabilities between Green Niches and Socio-Technical Regimes. Technology Analysis \& Strategic Management 19:4, 427-450

Smith, A., Stirling, A., Berkhout, F., 2005. The governance of sustainable sociotechnical transitions. Research Policy 34, 1491-1510. 
Smith, A., Stirling, A., 2007. Moving Outside or Inside? Objectification and Reflexivity in the Governance of Socio-Technical Systems. Journal of Environmental Policy \& Planning 9, 351-373.

Smith, A., Voß, J-P., Grin, J., 2010. Innovation studies and sustainability transitions: The allure of the multi-level perspective and its challenges. Research Policy 39, 435-448.

SOU 2001:77. Handel med elcertifikat: ett nytt sätt att främja el från förnybara energikällor: slutbetänkande / av Elcertifikatutredningen. Stockholm: Fritzes offentliga publikationer.

Spaargaren, G., Mol, A., 1992. Sociology, Environment and Modernity. Society and Natural Resources 5, 323-344.

Stenqvist, C., Nilsson Lars, J., Ericsson, K., Modig, G., 2011. Energy Management in Swedish pulp and paper industry - the daily grind that matters, eceee 2011 Summer Study, 6-11 June 2011, Belambra Presqu'île de Giens, France.

Stirling, A. 2011. Pluralising Progress: from integrative transitions to transformative diversity. Environmental Innovation \& Societal Transitions 1, 82-88.

Södra 2009. Södra i siffror. Retrieved 10 april 2010 at: http://www.sodra.com/sv/OmSodra/Sodra-i-siffror/

Teece, D. J., 2007. Explicating dynamic capabilities: The nature and microfoundations of (sustainable) enterprise performance. Strategic Management Journal 28, 1319-1350. 
Theliander, H. M., Paulsson, H., Brelid, H., 2002. Introduktion till Massa- och Pappersframställning. Göteborg: Chalmers Tekniska Högskola.

Thollander, P.,Ottosson,M.,2008. An energy efficient Swedish pulp and paper Industry — exploring barriers to and driving forces for cost-effective energy efficiency investments. Energy Efficiency 1, 21-34.

Thomasfolk, H., 2007. Interview with Hannu Thomasfolk, Mill manager at Rottneros Vallvik pulp mill. 2007-04-12.

van den Bergh, J.C.J.M., 2008. Optimal diversity: Increasing returns versus recombinant innovation. Journal of Economic Behavior and Organization 68, 565-580.

Van den Bergh, J.C.J.M, Truffer, B, Kallis, G., 2011. Environmental innovation and societal transitions: Introduction and overview. Environmental Innovation and Societal Transitions 1, 1-23.

Voß, J.-P., Bauknecht, D., Kemp, R., 2006. Reflexive Governance for Sustainable Development. Cheltenham: Edward Elgar. 
Table 1. Selected examples of investments reported to the SEA (2011b).

\begin{tabular}{|l|l|l|}
\hline Mill Annual net & Type of investment \\
reduction $\quad$ in & \\
electricity & use & \\
(MWh) & \\
\hline Holmen Paper, & 3400 & New deculator pump in paper \\
\hline SCA Packaging, & 855 & machine nr. 12 (PM12) \\
\hline Stora Enso, Fors mill & 138 & Rebuilding of the mills ventilation \\
\hline Rottneros, Rottneros & 466 & system \\
\hline mill & & New and more efficient electrical \\
\hline
\end{tabular}


Table 2. Selected examples of measures reported to the SEA (2011b).

\begin{tabular}{|c|c|c|}
\hline Mill & $\begin{array}{l}\text { Annual net } \\
\text { reduction in } \\
\text { electricity use } \\
\text { (MWh) }\end{array}$ & Type of process innovation \\
\hline \begin{tabular}{|l|} 
Holmen Paper, \\
Hallsta mill
\end{tabular} & 9600 & $\begin{array}{l}\text { Optimization of the vacuum } \\
\text { system }\end{array}$ \\
\hline $\begin{array}{l}\text { Stora Enso, Nymölla } \\
\text { mill }\end{array}$ & 3444 & $\begin{array}{l}\text { Improved aeration in activated } \\
\text { sludge plant }\end{array}$ \\
\hline $\begin{array}{l}\text { Billerud, Karlsborg } \\
\text { mill }\end{array}$ & 1199 & Optimization of pumps \\
\hline $\begin{array}{l}\text { Holmen Paper, } \\
\text { Braviken mill }\end{array}$ & 3400 & Optimization of fans \\
\hline $\begin{array}{l}\text { Billerud, Skärblacka } \\
\text { mill }\end{array}$ & 1000 & $\begin{array}{l}\text { Optimization of the recovery } \\
\text { boilers exhaust gas fans }\end{array}$ \\
\hline
\end{tabular}

